\title{
九州大学のアクションプラン
}

\section{梶 山千里}

\section{総長就任前後のこと}

私が九州大学総長に就任したのは平成 13 年 11 月です。 まずこの時の九州大学内外の状況を簡単に述べておきま す。

九州大学は平成 12 年 4 月に全学で大学院重点化を完了 し, 同時に, 「学府・研究院制度」という新制度を設けまし た。この制度は, 大学院の教育・研究組織である「研究科」 を, 大学院学生の所属する教育組織「学府」と, 教員の所 属する研究組織「研究院」とに分離することで, 新たな展 開を図るための教育・研究組織づくりに，柔軟に迅速に対 応することを可能にしようとしたものです（図 1)。この 「学府・研究院制度」の理念を空間的に実現して世界レべ ルの COE (センター・オブ・エクセレンス) 構築の器とな るべき新キャンパスで，工学研究院が平成 17 年 10 月よ り教育・研究活動を開始しました。

「新キャンパス建設と病院再開発, それに加えて, 国立大 学法人化を迎えることになる九州大学の総長とは, 何とた いへんな役を引き受けられたことか。」総長就任が決まっ たとき以来，異口同音にそう言われますが，私はいつもこ う答えています。

「国立大学法人化を, 新しいキャンパス, 新しい病院で迎 えることができることは, 九州大学の発展にとって千載一 遇のチャンスです」。

\section{法人化を越えて一「4-2-4 アクションプラン」}

平成 16 年 4 月に実施された国立大学法人化は，自主的 自律的な大学運営・経営体制, 民間的発想の導入, 非公務 員型人事システム，第三者評価機関による評価に基づく改 革サイクルの確立などによって,「個性輝く大学」づくりを

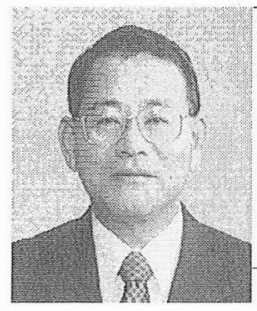

KAJIYAMA, Tisato 国立大学法人九州大 学 (812-8581 福岡市東区箱崎 6-10-1) • 総長, 工学博士 (Ph.D.). 1969年アメリカ合 衆国マサチューセッツ大学大学院高分子工学 科博士課程修了. 専門は高分子構造・物性, 有機材料.

Challenge of Kyushu Univ.

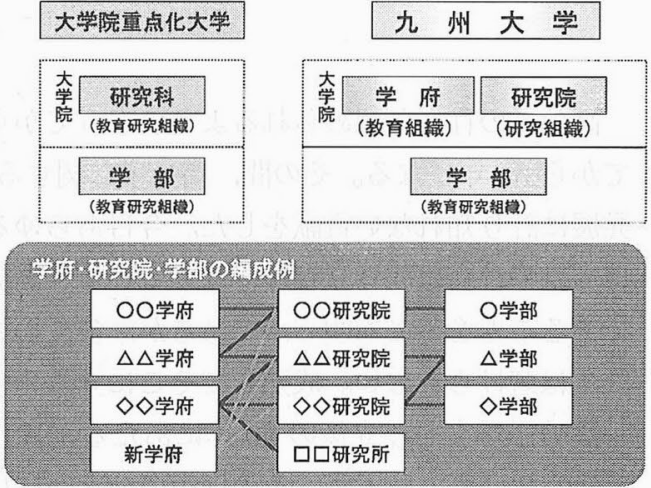

図 1 九州大学の学府・研究院制度

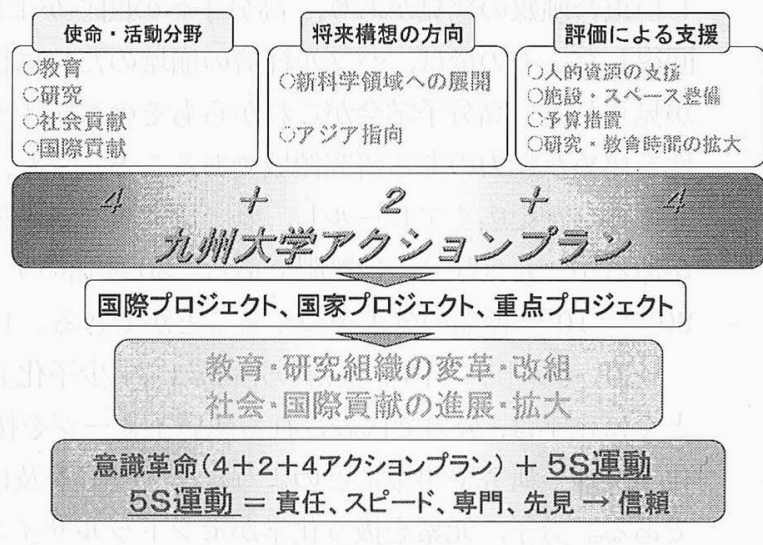

図 2 4-2-4 アクションプラン

目指すというあので，それまで横一列の平等主義で運営さ れてきた国立大学にとっては文字どおり大変革でした。

九州大学の法人化体制を円滑にスタートさせ, 法人化体 制下での生き残りをかけた本格的な競争に勝ち,「世界最 高水準の教育研究拠点 (COE) 形成」を実現するために, 私 は「4-2-4アクションプラン」と呼ばれる行動計画を掲げ ました（図2）。

$\lceil 4-2-4 」$ 最初の「4」は, 九州大学の使命であり活動分 野である「教育」,「研究」,「社会貢献」「国際貢献」を指 します。「2」は, 将来構想の方向性を示し,「実績に基づく 新科学領域への展開」之「歴史的・地理的な必然が導くア ジア指向」です。最後の「4」は評価に基づく大学からの支 援の中身を意味しており,「人的資源」「施設・スペース整 備」「予算措置」「教育・研究のための時間の拡大」です。 
横一線の平等主義は，大学間だけでなく大学内においてて 崩す必要があります。大学のむつ各分野を平均してレベル アップしようとするのではなく, 特定の教員個人や組織に 資源やエネルギーを集中して，いくつかの強み（ピーク） をつくることが，大学のブランド力を高める方策のひとつ です。

\section{ブランド戦略一「研究スーパースター支援 プログラム」と「戦略的教育・研究拠点形成」}

国際的に卓越した研究拠点づくりには，まず，独創的・ 創造的で高レベルの研究者の獲得之研究集団の組織構築が 不可欠です。「研究スーパースター支援プログラム」は, 「4-2-4」の最後の「4」を教員個人に対して実施したあの で, 平成 16 年 12 月に発表しました。

選ばれたスーパースターは,

(1)「21 世紀 COE プログラム」の拠点リーダー8名

(2)国内外において専門研究分野のみならず，学術振興や

社会連携で目覚しい活躍をしている確立した (senior) 研究者 11 名

(3)今後, 九州大学あるいは日本を背負って立ち, ス一 パースターとなることが期待される若手 (junior) 研究 者 20 名 の計 39 名です。

平成 17 年には, 研究グループ (組織) に対する重点的支 援を開始しました。「未来化学創造センター」「システム LSI 研究センター」「バイオアーキテクチャーセンター」 「デジタルメディシン・イニシアティブ」「アジア総合政策 センター」の五つのセンターを「戦略的教育・研究拠点」 として新設しました。

「研究スーパースター」と「戦略的教育・研究拠点」とい う教員個人之組織に対する支援は, 総長がリーダーシップ をとって決定したあので，10２0 年後を見据えた，世界 的な教育・研究拠点づくりにのための先行投資なのです。

\section{「知」の社会還元一組織対応型産学連携}

法人化後を意識して, 九州大学は新しいビジネスモデル として「組織対応型産学連携」を企業に提案し, 平成 15 年 3 月にはこの新スタイルでの共同研究がスタートしまし た。私自身, 企業の担当者の方々に直接会って, 九州大学 型ビジネスモデルの特徵を説明して回ったあのです。

従来型の連携は,「企業」対「教授 (講座)」の線的関係で したが,「組織対応型産学連携」は, これを「企業」対「大 学の研究グループ」, さらには「企業コンソーシアム」対 「大学コンソーシアム」など面的関係に高めたむのです。

共同研究の進行状況のチェックや知的財産の配分など, 共同研究に関するあらゆる問題を, 企業と大学双方のス
タッフからなる「連携協議会」が全責任をむって解決して いきます。これにより, 共同研究遂行中の研究組織の再編 成や, 研究内容の変更などが容易になり, 従来の, 単に課 題を解決するだけの問題解决型連携から，新たな展開を生 む可能性を有する課題発展型の共同研究体制となっていま す。また, 共同研究のス夕ート時加ら, 企業や大学の研究 者が互いの研究室を利用して共同研究を推進する形式に なっていることも, 従来型の大学における共同研究体制と 異なるところです。平成 17 年 11 月末現在で, 九州大学の 組織対応型連携契約は 30 件を数えています。将来は九州 大学之同種企業の連合体との共同研究，すなわち産業別包 括型産学連携に発展させたいと思っています。九州大学之 中国の上海交通大学との信頼関係を軸にした日中両国の産 業の交流, つまり国際産学連携む具体的な成果を生んでい ます。

このような組織対応型産学連携の目覚ましい推進は, 平 成 15 年 10 月に文部科学省の支援により設置された知的 財産本部之，そのメンバーである産学連携チームの活躍に 強く依存しています。産学連携チームは，国内外でビジネ スマインドと社会貢献のノウハウを身に付けた文系，理系 を問わない若い教職員で構成されて㧍り, 異なった文化と 経験を身に付けた集団が，九州大学の社会貢献活動の進展 に，個々の特色をいかんなく発揮しています。

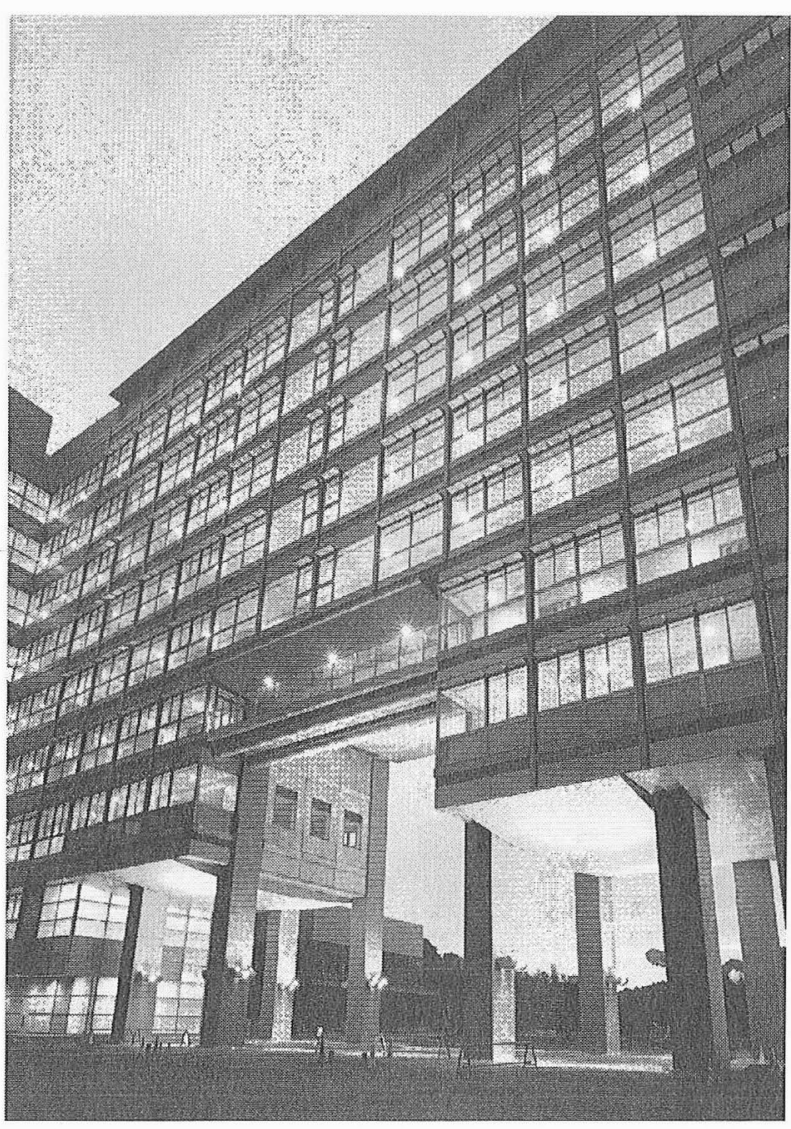

図 3 平成 17 年 10 月 1 日にオープンした伊都キャンパス 


\section{持続する発展一新キャンパス構想}

平成 17 年 10 月に第 1 期開校を迎えた新キャンパスは, その辺りがかつて伊都国之呼ばれ大陸との交流が盛んで あったことなどから，「伊都（いと）キャンパス」と命名さ れました。東西約 $3 \mathrm{~km}$, 南北約 $2.5 \mathrm{~km}$, 総面積約 $275 \mathrm{ha}$ という広大な用地に, 移転が完了すれば, 文系, 理学系, 工学系, 農学系や運動施設, 農場, そしてかねて加らの悲 願であった全学教育あ同居することになります。有名建築 家も加わってマスタープランや各地区の基本設計が決めら れ, さらに多くの㕡智によって景観や利便性に配慮した人 間味豊かな設計やデザインがなされています。

伊都キャンパスはまた，IC カードや水素エネルギーを 使った社会を実現させるための実証実験の場，地域や国家 プロジェクトのセンターとしても利用されようとしていま す。平成 10 年 5 月に, 福岡県, 福岡市, 九州・山口経済連 合会そして九州大学を中心に「九州大学学術研究都市推進 協議会」が設置されて, キャンパスを核とした学術研究都 市構想がス夕ートしています。平成 16 年 10 月には「(財) 九州大学学術研究都市推進機構」が設立され, 構想は実現
に向けて具体的に動き始めました。

伊都キャンパスがこれからどのようなキャンパスになる かは，日本の高等教育が今後どう変わるかを考える必要が あります。これから学生は，自宅や図書館など教室外で授 業を受けることができるようになるでしょうし，それゅえ に，キャンパスの機能が大きく変わる可能性があります。 大学キャンパスは, 従来までの教育や研究の場という機 能に，学生や教職員だけでなく，一般の市民などさまざま な人々が集まるコミュニケーションの場, 生活する場など 多様な機能を加えていかなくてはなりません。伊都キャン パスは, 国内外の研究者がキャンパス内に宿泊し生活して 参加する国際会議など大イベントの舞台とすなります。ま た，一般市民が，図書館や博物館を訪れてキャンパス内で 開催される公開講座, 演劇, コンサートを楽しみ, スポー ツ施設で汗を流す，そういう知的生活の一部として利用す る場としなければなりません。

伊都キャンパスを，そのような 21 世紀の大学キャンパ ス像を提示するあのにしたいと，夢を膨らませているとこ ろです (図 3 )。 